\title{
Reflection and Improvement of the Principle of Treating Invalid Construction Contracts as Valid in the View of Civil Law
}

\author{
Houyi $\mathrm{He}^{1} \&$ Jia Zeng ${ }^{2}$ \\ ${ }^{1}$ Faculty of Law, Chinese University of Hong Kong, Hong Kong, China \\ ${ }^{2}$ Faculty of Finance, Guangdong University of Finance and Economics, Guangzhou, China \\ Correspondence: Houyi He, Faculty of Law, Chinese University of Hong Kong, Hong Kong, China. E-mail: \\ HeHouyi0824@link.cuhk.edu.hk
}

Received: December 20, 2021

Accepted: January 15, 2022

Online Published: January 25, 2022

doi:10.20849/ajsss.v7i1.979

URL: https://doi.org/10.20849/ajsss.v7i1.979

\begin{abstract}
After the construction project is completed, if the contract is judged as invalid by the court at this time, it will involves the application of Article 157 of the Civil Code of People's Republic of China: For example, how to return the completed construction, how to compensate for the discount if it cannot be returned, and what standard should be adopted for the discount compensation. In order to solve the above problems, the Supreme People's Court issued the "Interpretation on the Application of Law to the Trial of Construction Contract Disputes" (hereinafter referred to as "Interpretation"), which mentions that the above problems should be regulated in judicial practice through the invalid construction contract "treated as valid". However, the principle encounters many difficulties both in theory and practice. For example, how to avoid its counterproductive effect of encouraging the signing of invalid contracts to destroy the market order, whether to use the contractual standard or the engineering quota standard in the project settlement, and how to interpret the scope of "effective" to better protect the rights and interests of the parties. This paper mainly discusses the background of the development of construction industry from 2005 to 2020, the definition of the principle of invalid building construction contract, the applicable situation, the limitations in theory and practice, and the final reflections and countermeasures.
\end{abstract}

Keywords: construction contract, engineering quota standard, invalid contract treated as valid

\section{Introduction}

Article 2 of the Interpretation stipulates that "If the construction contract is invalid, but the construction work is completed and accepted, the court shall support the contractor's request to pay the construction price with reference to the contract agreement." This article is also the legal basis of the principle that the invalid construction contract is treated as valid. The original intention of this article is to protect construction workers' income and curb the phenomenon of frequent default of construction workers' wages by contractors in the construction industry, so it has to sacrifice the basic civil law principle that contracts need to meet the basic constitutive elements stipulated by law to be effective. The first part of this article focuses on the impact of China's economic performance in the past 15 years on the real estate and other construction industries, in order to help readers understand the legislative purpose and legislative background of Article 2 of the Interpretation.

\section{Background on the Development of the Construction Engineering Industry From 2005 to 2020 in China}

A construction contract, i.e., an agreement stipulating the civil relationship between two parties with construction works as the subject matter and mutually agreed by the contractor and the contractor, which stipulates that the contractor will complete the construction works and receive remuneration after acceptance by the contractor. In recent years, the development environment of the real estate industry, which is mainly based on construction works, has deteriorated. 


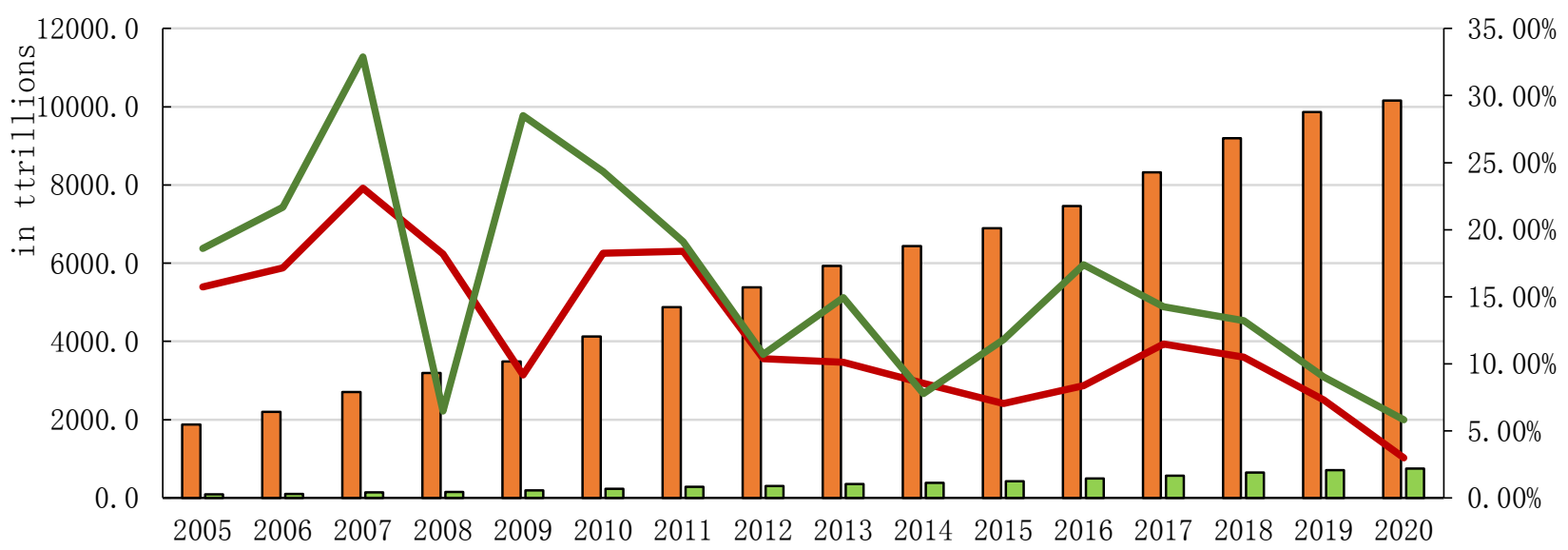

GDP GDP from Real Estate - Growth Rate of GDP - Growth Rate of GDP from Real Estate

Figure 1. The amount(RMB) and Growth Rates of Total GDP and GDP from Real Estate in China

During the same period, the Chinese government implemented a policy combination of accommodative monetary policy and fiscal policy for the domestic macro economy. In terms of fiscal policy, in November 2008, the Chinese government successively launched ten measures to expand domestic demand and promote economic rebound, increasing government spending by four trillion dollars in two years, supplemented by plans to increase export tax rebates, adjust labor laws, strengthen public finance spending on social security and medical care, and directly stimulate real estate development; in terms of monetary policy, the central bank successively stopped issuing three-year central bank notes, reduced the frequency of one-year and three-month central bank bills, and reduced the frequency of issuing one-year and three-month central bank bills, and lowered the benchmark interest rate and spring reserve ratio for four consecutive months, which indirectly increased the growth rate of money supply, supplemented social liquidity, and indirectly stimulated real estate development.

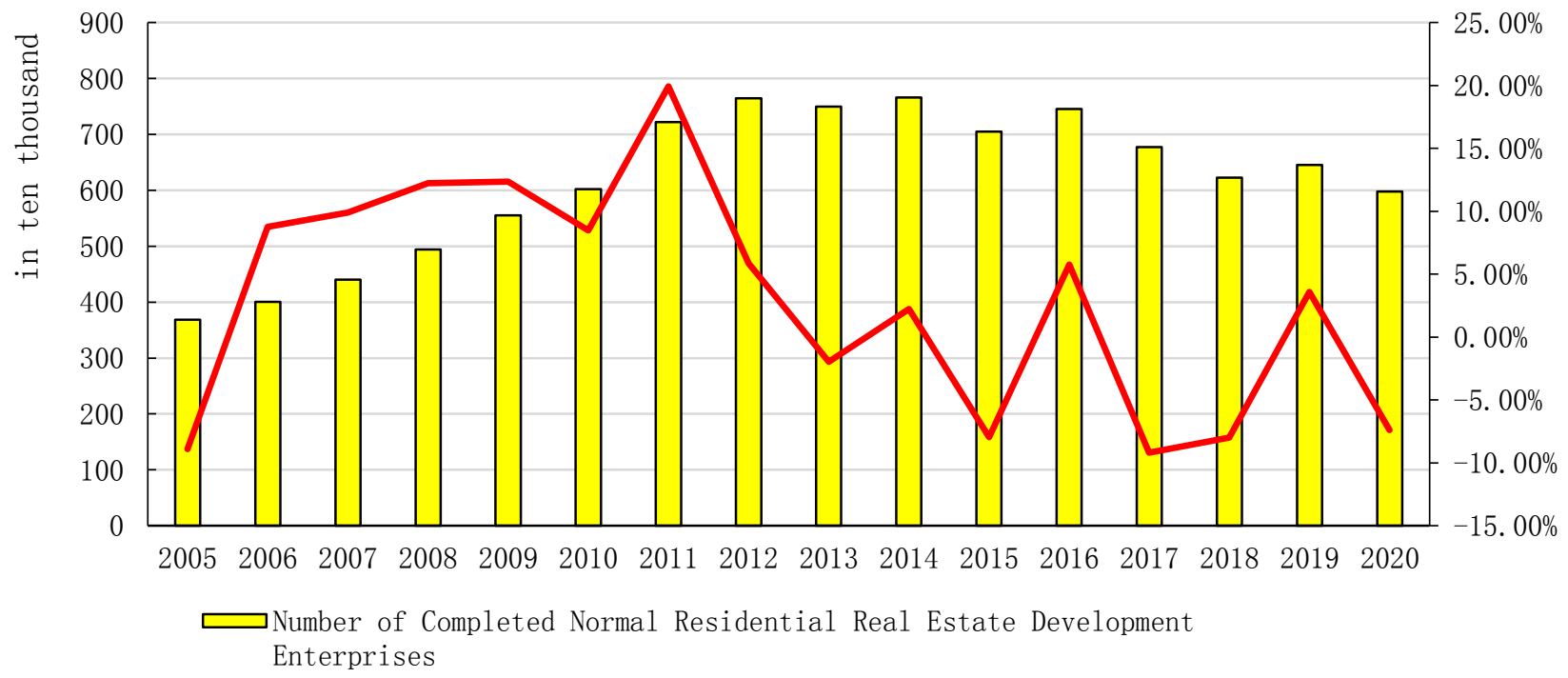

Figure 2. The Number and Growth Rate of Completed Normal Residential Real Estate Development in China 
The above-mentioned government actions in the short term made the output growth rate of the real estate industry rebound to $28.49 \%$, but due to the public fear of the real estate industry is difficult to calm down in the short term, the growth rate is on a downward trend. 2005 to 2020 the number of completed sets of domestic real estate development enterprises grew from 3682523 to 5976595 sets, the growth rate rose from $-8.90 \%$ to a very high point in 2011 19.92\%, gradually oscillating back down to $-7.38 \%$ in 2020 . This indicates that domestic real estate developers have tightened their real estate construction projects since the subprime mortgage crisis, and the number of construction completions has fallen year after year since near 2011.

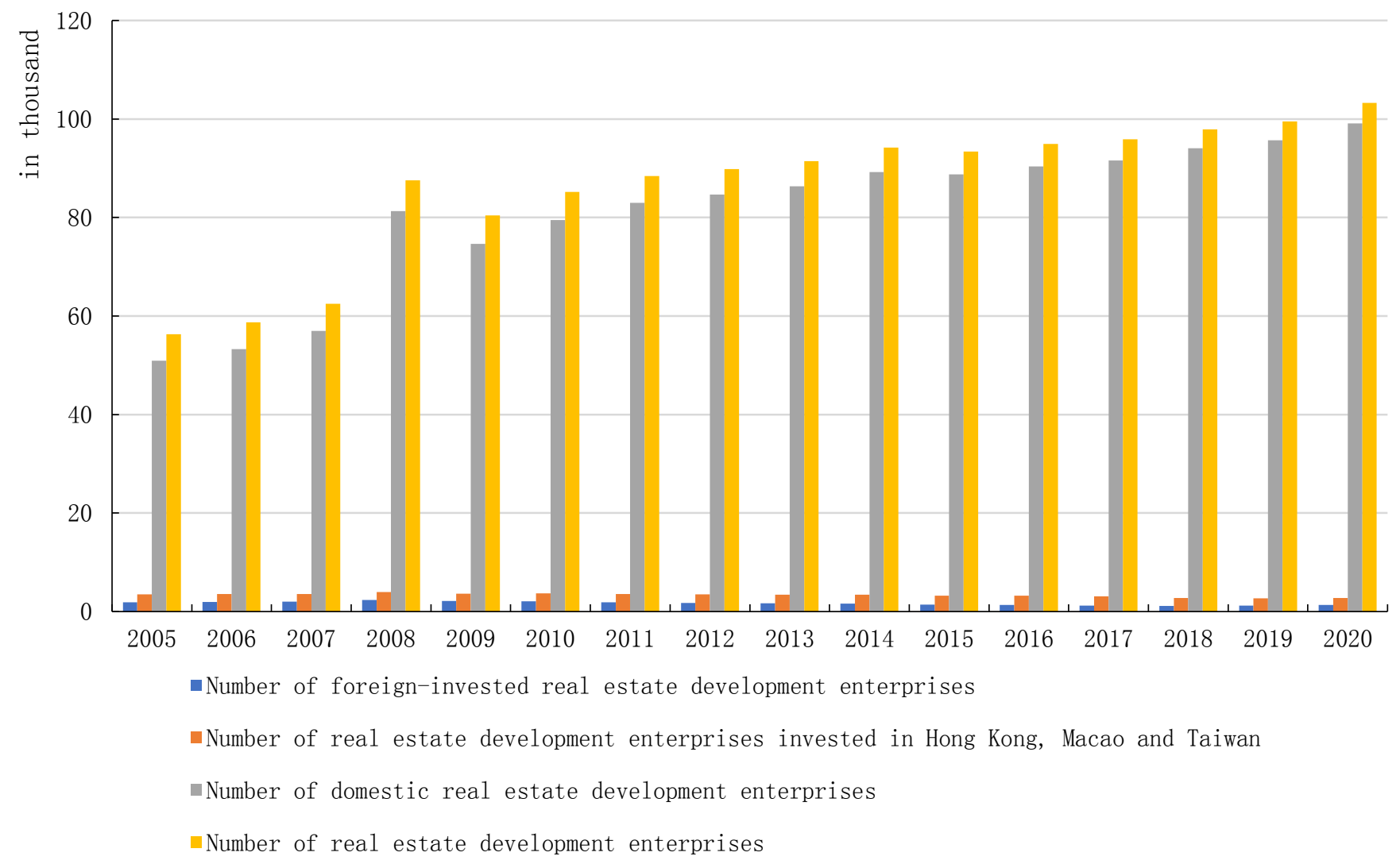

Figure 3. The Number of Total and Specific Real Estate Development Enterprises in China

At the same time, a batch of fresh blood continues to pour into the wave of domestic real estate development. 2005 to 2020, the number of domestic real estate development enterprises soared from 29552 to 103262 , an average annual increase of 3132 , of which the number of domestic real estate development enterprises grew most rapidly, from 25509 to 81282 in 2008, and then rose to 99150 after a short period of consolidation. 99150, an average annual increase of 3213; while Hong Kong, Macao and Taiwan real estate development enterprises and foreign-invested real estate development enterprises since the subprime crisis have withdrawn from the domestic real estate market, respectively, from 3916, 2364 in 2008 to 2759, 1353, an average annual decrease of 46, 36.

The withdrawal of foreign capital from the domestic real estate market and the rise of domestic capital have led to a rapid increase in the number of construction contracts, which has pushed up China's GDP to a large extent while also bringing about a large number of civil disputes. According to statistics, from 2011 to 2020, the total number of construction contract disputes in China increased from 70 cases to 7118 cases, with an average annual growth rate of 783 cases and an average annual growth rate of $102.23 \%$, among which the number of valid construction contract disputes increased from 9 cases to 3327 cases, with an average annual growth rate of 368 cases and an average annual growth rate of $146.20 \%$; while the number of invalid construction contract disputes The number of invalid construction contract disputes increased from 61 cases to 3791 cases, with an average annual growth rate of 414 cases and an average annual growth rate of $98.48 \%$. In this kind of invalid contract cases, many contractors refuse to fulfill the contract on the ground of invalid construction contract. 


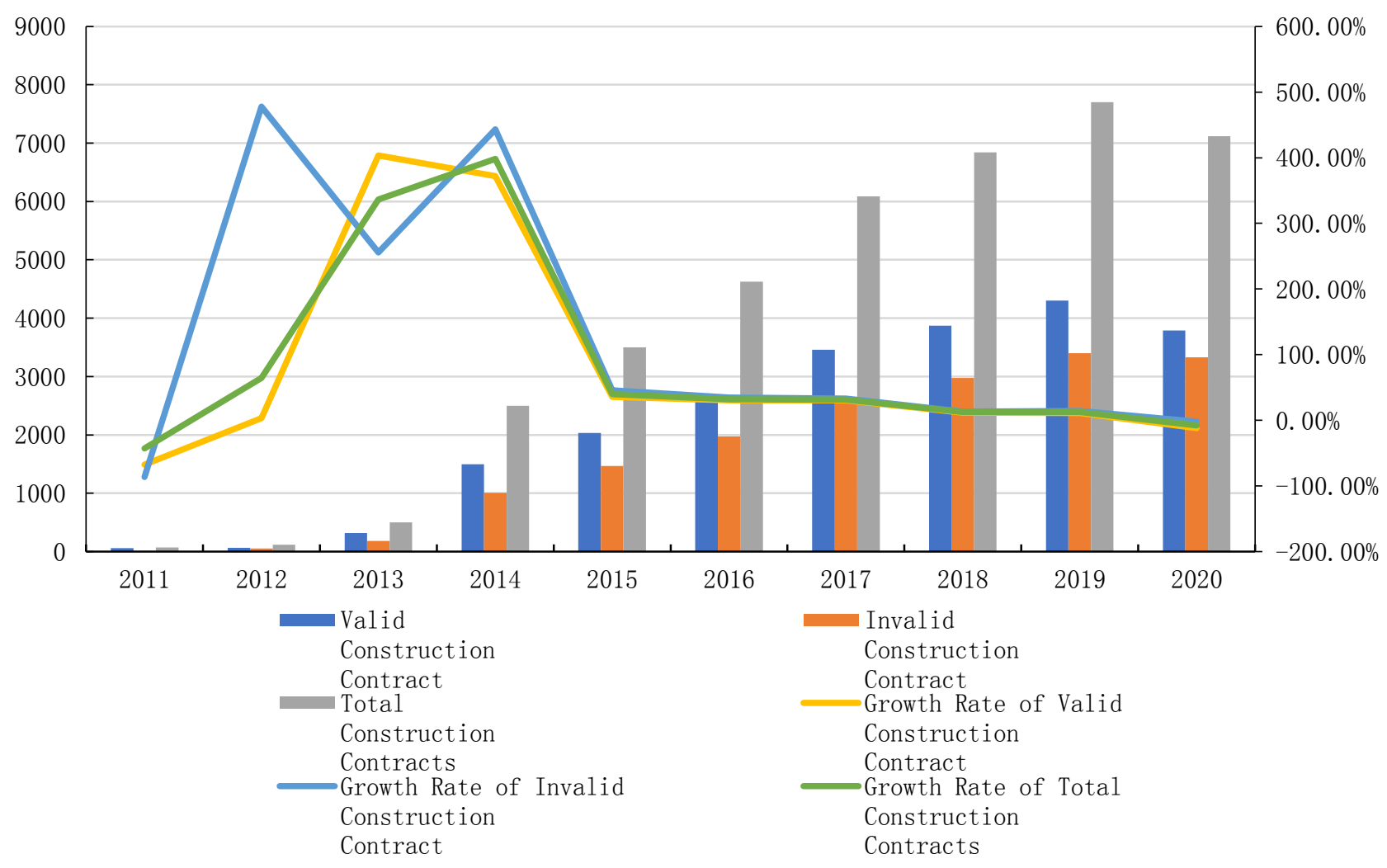

Figure 4. The Number of Dispute from Construction Contracts in China

The contractor, on the other hand, is in breach of the contract with the contractor, making it impossible for the actual builder (who is often a no-fault party) to get the salary payment. Contractors "run away with the money", the majority of construction workers "door-to-door payroll" chaos after chaos, the construction market labor relations continue to deteriorate, resulting in many social vicious events seriously damage the social harmony and stability. Therefore, the Supreme People's Court issued the Interpretation in 2004 to protect the legitimate rights and interests of the parties concerned, with a view to effectively alleviating social conflicts.

\section{The Current State of the Theory of the Principle of Treating Invalid Construction Contracts as Valid}

As the Civil Code is the basic civil law, the Interpretation issued by the Supreme Court of China definitely cannot go beyond the provisions of the Civil Code. In addition, the relationship between the two is neither general law and special law, nor superior law and inferior law. When the two conflict with each other, it becomes a question whether the court should apply the law or the judicial interpretation. Before the discussion, this article firstly elaborates on the definition and application conditions of the principle of validity of invalid contracts.

\subsection{Definition of Invalid Constructions Contracts Treated as Valid}

According to the Interpretation: Firstly, regardless of the construction contract (hereinafter referred to as "the contract") for what invalid, as long as the final project completion and acceptance, the people's court shall support the contractor's claim to pay the price of the project in accordance with the contract; Secondly, the contract is invalid, and the quality of the construction project tested by the relevant departments is not eligible, after the contractor expressly agreed (written consent), the contractor is liable to repair the project and pay for their own costs, if the repaired construction project meets with the national construction standards, the People's Court should support the contractor claim to pay the price of the project with reference to the contract.

\subsection{Four Common Situations in Which Construction Contracts Are Invalid}

First, the actual builder who does not meet the requirements of national compulsory laws and regulations borrows the license of a qualified building construction unit to undertake the project. The Regulations on Quality Management of Construction Works and the Construction Law clearly prohibit the contractor from contracting 
for works in the name of any non-contractor (such as dependency), and prohibit the contractor from allowing any non-contractor unit or individual to contract for works in the name of the contractor. If the court finds that the above-mentioned contractor belongs to the above-mentioned situation, the construction contract will be sentenced to be invalid. In addition, according to Article 35 of "Regulations on Construction Enterprise Qualification Management", if a construction contractor buys, sells or rents "Construction Enterprise Qualification licence" in any way, the business administration department shall order the contractor to rectify the situation within a certain period of time and impose confiscation of the illegal income (fluctuating from $2 \%$ to $4 \%$ of the contract amount in the range of the illegal situation), and if the situation is particularly serious or extremely bad in nature, the qualification certificate may be revoked. The qualification certificate can be revoked. Secondly, the construction must take the bidding method and the contractor did not bid, or invalid bid. "Bidding Law"and the relevant national and local laws and regulations on the scope and scale of construction works must be bidding conditions made mandatory, if the construction works must be taken to tender for the contract and the contractor did not tender or invalid tender, the contract is invalid. Thirdly, the contractor subcontracts the construction work. If the contractor subcontracts all the works contracted by the contractor or subcontracts all the works after dismemberment, the construction contract will be invalid due to the violation of the mandatory provisions of Article 78 of the Construction Works Quality Management Regulations. Fourthly, the contractor subcontracts the contracted works. Illegal subcontracting refers to: the construction work is subcontracted by the general contractor to other construction units that do not meet the legal qualification; the contractor hands over part of the construction work (whether or not it is the main body of the building) to other units (whether or not it has the legal qualification) to complete without the consent of the contractor, and there is no additional agreement in the contract; the subcontractor subcontracts the work it has contracted for twice or more. If the contractor meets the above circumstances, the contract is invalid.

\subsection{Deficiencies in the Theory of Applying the Principle of Treating Invalid Construction Contracts as Valid}

This principle contradicts with the legislative purpose of Article 157 of the Civil Code of People's Republic of China. According to the Interpretation, after the construction contract is recognized as invalid by the court, the people's court shall support the claim of the contractor to pay the construction price with reference to the contract after the acceptance of the construction work agreed in the contract. However, when we carefully check Article 157 of the Civil Code, we can find that the Civil Code takes the attitude of "restoring the original state and repairing social relations" after the contract is invalidated or revoked (original text: the property acquired by the contract shall be returned), even if it is due to the special nature of the subject matter of the contract itself from the factual or legal point of view. Even if the subject matter of the contract cannot be restored to its original state, cannot be returned, or even need not be returned due to its special nature, the parties to the contract shall compensate at a discount, and the party at fault shall be liable for contractual negligence or other tort liability based on "impaired reliance", and compensate the other party in good faith for the direct loss (the loss of human and material resources spent on concluding the contract) and indirect loss (if the contract is properly concluded) If both parties are at fault, they shall be liable in proportion to the direct loss (the loss of human and material resources spent on the conclusion of the contract) and indirect loss (the benefit that could have been expected if the contract had been performed properly). This means that after the contract is declared null and void, there are three ways to deal with it: return of the original goods, compensation at a discount, and compensation for damages. The judicial interpretation of the Supreme Court "construction contract is invalid according to the validity" contradicts the above provisions of the Civil Code, and we can find that Article 157 of the Civil Code does not leave room for the implementation of the interpretation of the Supreme Court.

Some scholars argue that the interpretation of the Supreme Court is an expansion of the "discounted compensation" of the Civil Code. However, the other scholars argue that this is inappropriate. First, the "discount compensation" reflects the characteristic of "non-performance". The "non-performance" refers to the termination of contract performance due to the initial invalidity of the contract, while the Interpretation of the Supreme Law clearly implies that its legislative purpose is to encourage the continued performance of the contract. After a construction contract is declared invalid due to illegal reasons, if the project is accepted, or if the project is not accepted, and the contractor is willing to repair it at its own expense and make the project meet the acceptance standard within the contract period, the contractor can also request the contractor to pay for the project. All signs indicate that the Supreme Court's Interpretation is entirely to encourage the continued performance of the contract. Compared with the "non-performance" embodied in Article 157 of the Civil Code, the two are obviously in conflict with each other, because the latter is more in pursuit of the restoration and repair of social relations, to achieve the legislative purpose of social stability, so that the personal and property relations between the parties to restore to the ideal state before the contract. Secondly, the discount compensation also embodies a 
kind of "fault compensation", the so-called "fault compensation" means that the party at fault should bear the fault responsibility for the consequences of the contract becoming invalid, and compensate the other party for the loss of the contract, both parties are at fault. If both parties are at fault, the fault liability is divided according to the degree of fault of each party, so as to reflect the principle of fairness and honesty and trustworthiness of civil law. However, the Interpretation of the Supreme Law does not reflect this feature, so it is obviously biased to think that the "invalid contract according to the validity of the relevant provisions" in the Interpretation of the Supreme Law is a special manifestation of "discount compensation".

\section{The Dilemma of Application of Treating Null and Void Construction Contract as Valid}

\subsection{Causing a Party to a Contract to Enter Into an Invalid Construction Contract in Bad Faith}

With the rapid development of China's construction industry and the acceleration of urbanization, a large number of migrant workers are pouring into cities, and the phenomenon of unqualified contractors illegally contracting for construction works is common. The original purpose of the Construction Law and the relevant provisions of the Construction Project Quality Regulations is to combat such illegal contracting phenomenon, purify the market environment and improve the quality of construction works, but now the new Interpretation promulgated by the Supreme Court seems to have a tendency to run counter to this original purpose. In the "Answer to a Reporter's Question on the Interpretation of Applicable Law for Hearing Construction Contract Disputes", the Supreme Court has explained on this issue: "When the construction contract is confirmed to be invalid, there are two ways of discount compensation, one of which is to take the project quota as the standard, that is, to determine the value of the construction project through appraisal." According to a large number of disputes about construction construction contract that the author of this paper learned in the process of trial in the Civil Division of Huizhou Central Court, it is known that the contractor often tends to press the contracted construction amount to close to the cost price to improve the market competitiveness in order to promote the establishment of the contract, if the invalid contract adopts the professional institution appraisal to determine the construction value when settling the construction amount instead of the amount determined according to the agreement of the previous contract, it has If the invalid contract in the settlement of the construction project using professional institutions to determine the value of the construction project rather than the amount determined according to the previous contract, it may play a negative effect of encouraging the signing of invalid contracts, because the project appraisal to determine the settlement of the project will often be higher than the contractual agreement "has been squeezed" project settlement. In other words, the invalid contract not only has "discount compensation" clause as a means or way to increase revenue, there is also "invalid contract according to the effective treatment" principle of the legal basis to be used as a "resurrection of the dead "tool. It is conceivable that if such malicious pressure phenomenon is normalized, it will bring incalculable harm to the reasonable and healthy development of the construction industry and make the dignity of the law suffer a serious blow.

\subsection{In Practice, It Serves as a Bad Example and Destroy the Value of the Law}

According to Article 2 of the Interpretation, whether the invalid construction contract can be restored to effect depends on whether the quality of the construction work at the time of acceptance is up to standard, so does this also mean that the parties concerned will not need to care about the management of the contractor's construction qualifications in the future, such as the mandatory provisions of the law for projects that must be tendered. Because according to Article 2 of the above "Interpretation", it seems that as long as the construction works are accepted by the relevant departments, other illegal circumstances can be omitted, according to the experience of the author of this article in the Civil Court, we can find that even if the construction contract is invalid due to the lack of the corresponding legal elements, most of the contractual obligations of the parties will eventually be fulfilled, and disputes really occur There are few cases of "going to court" in general. Nevertheless, as a legal provision, it has an exemplary role in itself, if it really happens that there are parties to use the legal provisions of the loopholes, one-sided emphasis on whether the acceptance of the quality of the project, while ignoring the market fairness and justice, the legalization of the market and other values to obtain illegal benefits, not only will let the value of the pursuit of the law is empty, but also undermine the dignity of the law.

\section{Reflection and Improvement Measures}

5.1 It is appropriate for "the Completion and Acceptance of construction works" to be a necessary but not a sufficient condition for the principle of "invalid construction contracts are treated as valid"

The supreme court "interpretation" of article 2 and article 3 is the "construction project completion acceptance" as a sufficient necessary condition for the invalid construction contract according to the principle of effective treatment, meaning that the existence of the former must be able to deduce the latter, on the contrary, the existence of the latter can also be deduced from the former. This article believes that this is inappropriate, first of 
all, because according to the construction contract is invalid in several cases, different construction construction contract is invalid for different illegal reasons, if only the acceptance of the contract as the only effective element, then the meaning of the legal provisions set in different illegal reasons will be greatly reduced. Secondly, the "construction project completion acceptance" as a sufficient condition for the principle of "invalid construction contract according to the effective treatment" is suspected of oversimplification and one-sidedness of the problem. For example, one of the circumstances of invalid construction contract is that the construction contract is invalid if the construction project must be tendered but not tendered, or if the successful bid is invalid. Thus, the legislative intent of the provisions of the law is not only to ensure the quality of the project by awarding the project to qualified contractors, but also to ensure the transparency and fairness of the construction market environment equality, the democracy of the process, the equality of the subjects of enterprise participation in the market competition. If each enterprise unit and individual take the construction project completion acceptance as "imperial sword", ignoring other important market rules. Due to the spontaneous and disorderly nature of the market, the ecology of the construction market will suffer serious damage, the development of socialist market economy will also be overshadowed. In summary, this paper believes that in addition to the "construction project completion and acceptance", should also take into account the specific circumstances of the contract is invalid and the degree of fault of the parties to determine whether to deal with according to the validity.

\subsection{It is up to the court to decide whether the contract settlement should refer to the contractual standard or the engineering quota standard}

From the legislative intent, Article 2 of the Interpretation of the Supreme Law is essentially to make the subcontractor in the construction contract from bearing greater risk of loss, rather than giving the parties the right to choose to seek profits higher than those agreed in the contract; but only from the literal analysis, the article seems to give the contractor the right to choose to choose the standard of settlement of the project. In the process of practice research, the author worked in the Huizhou Central Court Civil Division, for example: if the parties to the contract have agreed on the contract, then according to the contract; if the parties to the contract have not agreed on the contract, then you can apply for identification; if the parties to the contract have agreed on the amount of the contract, but the contractor in the construction process within the scope of the contractor allowed the actual volume of work to increase or decrease If both parties to the contract have signed a contract and it is the unanimous intention of both parties, but the contract is much lower than the market price, after the contract is recognized as invalid, the contractor refuses to apply for appraisal with reference to the contract on the ground that the amount of work is much lower than the market price, and what standard is chosen by the judge according to the actual situation. The choice of the standard is left to the discretion of the judge according to the actual situation. Thus, in practice, the "contractor" in Article 2 of the Interpretation of the Supreme Court only appears in its name, not giving it the right to choose, and the real right to choose the standard is still in the hands of the judge.

\subsection{Engineering settlement standards should be the norm with reference to contractual agreements, with the exception of engineering quota standards}

In response to the chaos of certain contractors maliciously signed construction contracts at prices significantly lower than the market price, it is appropriate to refer to the contract agreement is not universal, in special circumstances before referring to the project quota standards. First, in favor of the embodiment of the principle of autonomy, if the contract is signed when the intention of the parties is true, and does not violate the mandatory provisions of the law, the effectiveness of the contract should be protected, the parties to the contract should also be bound by the contract. Therefore, even if the contractual settlement amount is much lower than the market price, the contractor, as one of the parties to the contract, should fully respect the terms of the contract, because the contractor did not object to it when the contract was signed. If the contractor applies for engineering appraisal with the price too low after the contract is confirmed to be invalid, it should also be a breach of contract. Some scholars believe that although this reflects the contractual spirit of the contract, it is contrary to the principle of fairness as one of the basic principles of the contract, because they believe that the low price of the project settlement payment is manifestly unfair. In this paper, the principle of autonomy is the most common principle to determine the governing law of the contract, its legal value is significantly higher than the principle of fairness, when the above two values conflict, it is appropriate to adopt the standard of "the lesser of two evils", that is, the principle of fairness gives way to the principle of autonomy. Second, the reference to the contract is conducive to improving the efficiency of litigation, to promote "case settlement" and improve the speed of "settling disputes and stopping them". Third, is conducive to curb the contractor "malicious pressure" behavior, purify the construction market environment, to protect the legitimate rights and interests of the parties. However, 
according to the specific circumstances of the case, if the project is not yet completed, or in the construction process to change the main framework of the building, the contractual agreement to calculate the amount of work is really difficult, according to the specific circumstances of the case can be commissioned to assess the actual amount of the project.

\subsection{Expanding interpretation of "valid" in the principle of "invalid building construction contracts are treated as} valid"

Whether the payment of construction contract is paid or not depends on the quality of the project, but is also linked to contractual obligations such as project warranty and project management. If the contractor refuses to fulfill the relevant contractual obligations on the ground that the "invalid construction contract is treated as valid" is only limited to the payment of the project amount, while other additional or supporting clauses are still invalid, it will definitely damage the legitimate rights and interests of the contractor. Therefore, this paper believes that it is appropriate to expand the interpretation of "effective processing", that is, in addition to supporting the request of the contractor to claim the construction money from the contractor after the quality of the project has reached the standard, it should also restore the effectiveness of other contractual obligations (such as regular maintenance) which are closely related to the payment conditions of the project settlement. Only in this way can we effectively curb the contractor from signing invalid contract in bad faith in violation of the principle of honesty and credit, so as to maintain the dignity of law.

\section{Conclusion}

The principle of effective handling of invalid construction contracts has been implemented so far, and some people applaud it, while others question it. Because of its highly controversial nature, this paper therefore proposes: (a) The establishment of the principle of "acceptance of project completion" as one of the conditions instead of the only condition is conducive to taking into account other important values, such as the fairness of the market. (b) The standard of project settlement should be based on the actual situation, contractual agreement, supplemented by project appraisal, which can fully respect the autonomy of meaning and also curb the malicious claim of invalid contract and bad market competition. (c) On the "invalid building construction contract according to the effective treatment" principle of "effective" to expand the interpretation, effective not only refers to the project settlement to achieve payment conditions, should include the contract supporting terms, such as liability for breach of contract, project management warranty, etc., to curb the malicious signing of Invalid contract has a certain effect. (d) Refer to the contract or the engineering quota standard to settle the option should be in the hands of the judge, by the judge according to the actual situation discretion, so as to protect the rights and interests of the parties, to combat the malicious signing of invalid construction contracts.

\section{References}

Pan, J.-H. (2014). Research on the shady issues of trial of construction contract cases (Vol. 7). Application of Law.

Sun, X.-H. (2016). Review of the effective treatment of invalid construction contracts (Vol. 5). Master's thesis, Southeast University.

Wang, W.-L. (2020). Legal Consequences of Invalid Construction Contracts for Construction Works - A Perspective on the Basis of Calculation of Project Price (Vol. 5). Xinjiang Social Science Forum.

Zhang, Q.-H. (2010). Prevention and handling of construction contract disputes. Law Press.

\section{Copyrights}

Copyright for this article is retained by the author(s), with first publication rights granted to the journal.

This is an open-access article distributed under the terms and conditions of the Creative Commons Attribution license (http://creativecommons.org/licenses/by/4.0/). 